\title{
STUDIES ON THE CIRRIPEDIAN FAUNA OF JAPAN -VII. CIRRIPEDS FROM SAGAMI BAY-
}

\author{
$\operatorname{AUTHOR}(\mathrm{S})$ : \\ Utinomi, Huzio
}

\section{CITATION:}

Utinomi, Huzio. STUDIES ON THE CIRRIPEDIAN FAUNA OF JAPAN -VII. CIRRIPEDS FROM SAGAMI BAY-. PUBLICATIONS OF THE SETO MARINE BIOLOGICAL LABORATORY 1958, 6(3): 281-311

\section{ISSUE DATE:}

1958-06-20

URL:

http://hdl.handle.net/2433/174591

RIGHT: 


\title{
STUDIES ON THE CIRRIPEDIAN FAUNA OF JAPAN \\ VII. CIRRIPEDS FROM SAGAMI BAY ${ }^{13}$
}

\author{
Huzio UTINOMI
}

Seto Marine Biological Laboratory, Sirahama

With 10 Text-figures

The present paper forms a part of a series dealing with the regional Cirripedian fauna on the Japanese coasts intermittently published since 1935, and is mainly based on the collection of Cirripedia Thoracica deposited in the Biological Laboratory of the Imperial Household which was recently submitted to me for study.

The material studied contains a few lot collected from other districts, but for the most part is that from the eastern region of Sagami Bay where the most extensive collecting has been done year by year. Localities for each species given in the text are mostly the local names of banks or shoals in that bay, unless otherwise mentioned.

Although the present collection is unexpectedly small, it may be of considerable interest both from a systematic and zoogeographic point of view, since a new remarkable primitive type of the Scalpellidae was found; it was already described in detail under the name Pisiscalpellum withersi n. gen. et n. sp. in a separate paper (Utinomi, 1958). The remaining species, comprising 22 species and subspecies in all, have been apparently already described, and all reported already from the Japanese waters, so that further detailed descriptions may be scarcely necessary.

In addition to this collection, eight more species are added which had not been as yet recorded from this district, but I have ever collected there, mainly at Misaki.

Lastly, a list of the Cirripedia Thoracica recorded from Sagami Bay and adjacent areas is given in order to make a faunistic comparison with the other parts of Japanese waters.

Here I wish to thank Dr. Hirotaro HATTORI of the Biological Laboratory of the Imperial Household and staff members for placing this interesting collection into my hand for examination.

1) Contributions from the Seto Marine Biological Laboratory, No. 310.

Publ. Seto Mar. Biol. Lab., VI (3), 1958. (Article 16) 


\title{
LEPADOMORPHA
}

\author{
Family Scalpellidae \\ 1. Calantica eos (PILSBRY)
}

Scalpellum (Calantica) eos PILSBRy, 1907, p. 9, fig. 2 (type locality: off Ose-zaki, Suruga Bay in 71 fathoms).

Calantica eos PILSBry, 1908, p. 106 ; Hiro, 1937a, p. 26, fig. 18.

Calantica eos longisquama Hiro, 1932a, p. 479, figs. 4a-f and 5d-e; pl. 30, figs. 3-3b.

? Scalpellum (Calantica) studeri WeLtNer, 1922, p. 100, pl. 3, figs. 13-13b (part).

Material. Crust. No. 138. 6 adult (12-28 $\mathrm{mm}$ long) and 2 juvenile (2.2-7 mm long) specimens attached to a hydrocoral Stylaster profundiporus forma typica BRoCH. Amadaiba, 70 fathoms. 16-VII-1934.

Crust. No. 144. 12 specimens attached to a stone. Off Zyôgasima Is., 50-70 fathoms. $22-$ VII-1935.

Crust. No. 202. One specimen attached to a hydrocoral Stylaster profundiporus forma typica BRoch. Amadaiba, 55 fathoms. 7-VIII-1936.

Crust. No. 204. One specimen attached to a hydrocoral Stylaster dentatus BROCH. Amadaiba, 50 fathoms. 9-VIII-1936.

Crust. No. 730. One specimen attached to an empty polychaete tube. Kadone, off Nagai, $100 \mathrm{~m}$.

Crust. No. 1315. 3 large $(40 \mathrm{~mm}, 45 \mathrm{~mm}$ and $46 \mathrm{~mm}$ long respectively) and 1 young (10 mm long) specimens. Aoyama-dasi, Amadaiba, 74-86 m. 17-VII-1957.

Range. Suruga and Sagami Bays only.

Remarks. As described before under the name Calantica eos longisquama (Hiro, 1932a), the relative length between the occludent and carinal margins in the capitulum is very variable in the present material too. The cuticle is smooth and yellowish brown. All the plates in the upper whorl are usually tinged with orange hue distally, and the scales in the peduncle are elongate, tiny and half buried in the cuticle. The specimens collected by OwSTON and DödERLEIN in Japan, probably from Sagami Bay, which were regarded by WeLtNer (1922) as Calantica studeri n. sp., may be referable to this species, although it is questionable whether WeLTNER's type material from West Australian coast and Three King Islands too is homogeneous or not.

\section{Smilium scorpio (AuRIVILlius)}

Scalpellum scorpio AuRIvillius. 1894, p. 46, pl. 3, figs. 6-8; pl. 9, figs. 10-13 (type localities: China Sea, south of Amoy, in $60 \mathrm{~m}$ and Hirado Strait, Japan, in $80 \mathrm{~m}$ ).

Smilium scorpio+sexcornutum PILSBRY, 1908, p. 107.

Smilium sexcornutum KRüGER, 1911, p. 15, pl. 1, fig. 2a; pl. 2, figs. 14-17.

Calantica scorpio HIRo, 1932a, p. 481; HIro, 1933a, p. 13, fig. 1; pl. 1, figs. 1-2 (synonymy); Hiro, 1937a, p. 29, fig. 21. 
Material. Crust. No. 201. 2 specimens attached to a bryozoan. Aoyama-dasi, Amadaiba, 55 fathoms. 7-VIII-1936.

Range. Common around the coasts of Japan northward to Kasima-nada on the Pacific coast side and to Toyama Bay on the Japan Sea side. Recorded also from China Sea and Gulf of Siam.

\section{Smilium acutum (HoEK)}

Scalpellum acutum HoEk, 1883, p. 80, pl. 3, fig. 19 ; pl. 8, fig. 12 (type localities: in the Atlantic near the Azores and in the Pacific near the Kermadec Islands).

Smilium acutum Hiro, 1933a, p. 17, pl. 1, fig. 3 (synonymy); Hiro, 1937a, p. 30, fig. 22.

Material. Crust. No. 201. One specimen ( $6 \mathrm{~mm}$ long and $2 \mathrm{~mm}$ wide) attached to a hydroid. Aoyama-dasi, Amadaiba, 55 fathoms. 7-VIII-1936.

Range. Widespread in deep-sea in all oceans.

\section{Pisiscalpellum withersi UTINOMI}

Pisiscalpellum withersi (n. gen. et n. sp.) UтіnomI, 1958, p. 113, figs. 1-3.

Material. Crust. No. 1181. 3 specimens (holotype and paratypes). Mosaki, Kamegi-syô, 5-6 fathoms. 23-VII-1956.

Range. Known only from the single locality mentioned above.

Remarks. This is a remarkably specialized scalpellid, apparently representing an intermediate state between the genera Calantica (Scillaelepas) and Scalpellum (Arcoscalpellum). Its detailed description, together with a discussion on the systematic position, were already given in a separate paper mentioned above.

\section{Scalpellum nipponense PILSBRY}

Scalpellum nipponense PILSBRY, 1907a, p. 73, fig. 29 (type locality; off Manazuru-zaki, Sagami Bay, between 120-265 fathoms).

Scalpellum intermedium Nilsson-Cantell, 1921, p. 208, fig. 33 (not Hoek, 1883).

Scalpellum nipponense BRoch, 1931, p. 24, fig. 9 (synonymy); HIRo, 1933a, p. 25, fig. 5; pl. 1, figs. 7-9b (synonymy); Hrro, 1937a, p. 43, fig. 34.

Material. Crust. No. 207. One specimen. Amadaiba, 300 m. 6-IX-1936.

Range. Pacific coast of Japan, from Kasima-nada to Tôtômi-nada.

\section{Scalpellum vitreum HoEK}

Scalpellum vitreum HoEx, 1883, p. 65 (type locality: $34^{\circ} 37^{\prime}$ Lat. N., $140^{\circ} 32^{\prime}$ Long. E., off Bôsô Peninsula, 1875 fathoms); Hrro, 1937a, p. 40, fig. 31.

Material. Crust. No. 138. One specimen attached to a hydrocoral Stylaster profundiporus forma typica BRoch, together with Calantica eos (PILSBRY). Amadaiba, 70 fathoms. 16-VII-1934. 
Crust. No. 1315. 2 specimens attached to Calantica eos (Pilsbry). Aoyama-dasi, Amadaiba, 74-86 m. 17-VII-1957.

Crust. No. 1447. One specimen on a gravel. WSW 2 miles of Zyôga-sima, 169230 m. 19-III-1958.

Description. Capitulum is long-oval, widest in the middle, composed of 14 wholly calcified plates, like the peduncle covered by a very thin and sparsely pilose cuticle. With the exception of carina and rostrum, the plates are sculptured with distinct riblets radiating from the umbones, not crossed by any transverse riblets or stripes.
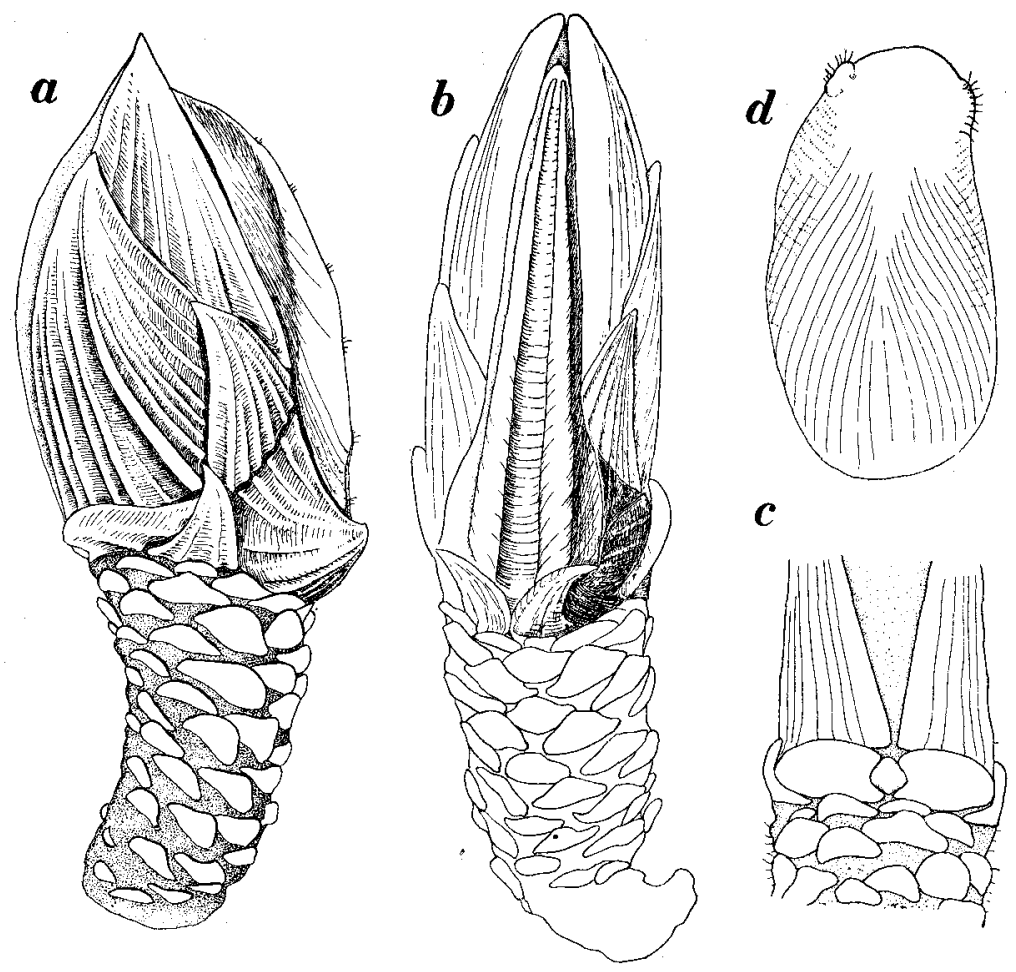

c

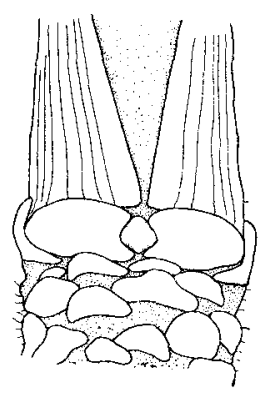

Fig. 1. Scalpellum vitreum НоЕк.

$a$, Animal (Crust. No. 138), lateral side. $b$, The same, carinal side. $c$, Rostral part. $d$, Complemental male. $\quad(a-c \times 9, d \times 70)$

Scutum trapezoidal, about half as wide as long, with beaked apex. Occludent margin convex; tergal, lateral and basal margins are straight, the basal shortest. There is a curved diagonal riblet from apex to basolateral angle, stronger than the other riblets.

Tergum triangular, with almost perfectly straight margins. Riblets radiating from the pointed apex are rather lower than those of scutum.

Carina evenly curved with apical umbo situated a little below the tip of capitulum. 
Dorsally a deep and broad longitudinal furrow runs from the apex to the basis, bounded by high and broad flanges along which about 6 tufts of short hairs are adorned. The sides are narrow below, wider above; basal margin concealed under two carinal latera.

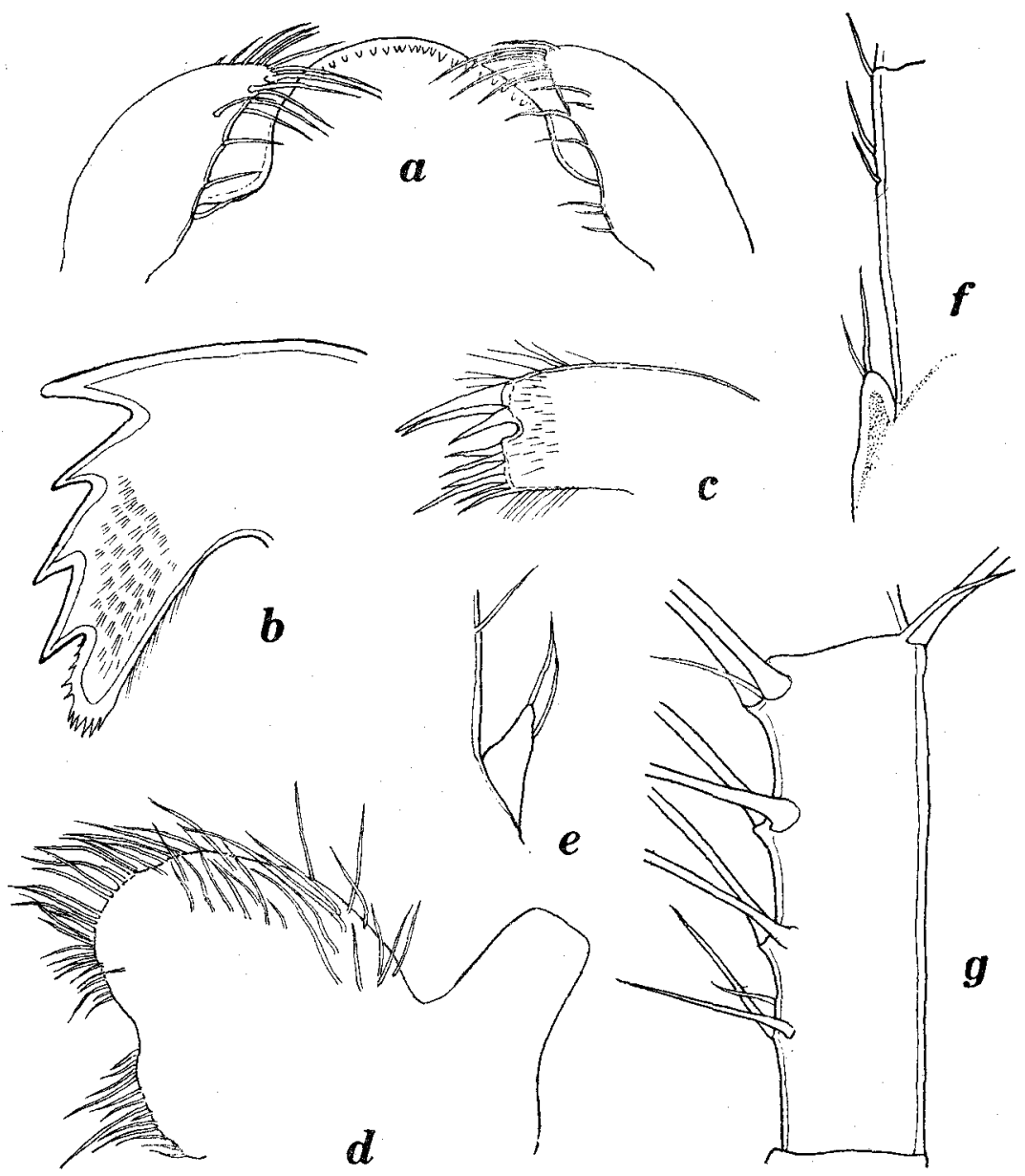

Fig. 2. Scalpellum vitreum HOEK.

$a$, Labrum and palpi. $b$, Mandible. $c$, Maxilla I. $d$, Maxilla II. $e, f$, Caudal appendage. $g$, Intermediate segment of cirrus VI. $\quad(a-f \times 95, g \times 150)$

Upper latus triangular trapezoidal with distinct riblets radiating from the umbo between the bordering scutal and tergal margins, so that the basocarinal margin may be slightly curved and undulated.

Rostrum very small, roughly quadrangular or lanceolate and wholly exposed, inserting between the rostral latera of both sides.

Rostral latus quadrangular, with the widest scutal margin almost parallel to the 
basal margin insensively continued from the lateral margin. Its rostral margin is shortest and hollowed out to meet at a rostrum. Umbo is apical, but radiating riblets not so distinct as in other plates.

Inframedian latus small, triangular, with the umbo at the strongly recurved apex. Radiating riblets distinct, 4 in number.

Carinal latus in lateral view is pentagonal, the carinal margin being divided into two parts at the umbo projecting beyond the carina below which the two latera meet. The upper part is slightly concave, the lower convex, and the upper slightly longer than the lower. Riblets running towards the upper margin are more distinct than those towards the lateral and basal margins.

Peduncle is cylindrical, gradually narrower downwards and shorter than capitulum. It is covered with large, transversely lengthened, scales in about 9 transverse rows of about 8 or 9 scales each.

$\begin{array}{lllll}\text { Cat. No. of specimens } & 1447 & 138 & 1315 \mathrm{a} & 1315 \mathrm{~b} \\ \text { Length of capitulum } & 8.5 \mathrm{~mm} & 7.0 \mathrm{~mm} & 2.5 \mathrm{~mm} & 2.0 \mathrm{~mm} \\ \text { Breadth of capitulum } & 5.5 & 4.0 & 2.5 & 2.0 \\ \text { Length of peduncle } & 2.2 & 4.5 & 1.5 & 1.8 \\ \text { Diameter of peduncle } & 3.2 & 2.0 & 1.3 & 1.3\end{array}$

Cirri show the following numbers of segments in a specimen dissected (Cat. No. 1315a).

$$
\overbrace{6 \quad 8}^{\text {I }} \overbrace{10 \quad 12}^{\mathrm{II}} \overbrace{13 \quad 12}^{\mathrm{III}} \overbrace{12 \quad 13}^{\mathrm{IV}} \overbrace{12}^{\mathrm{V}} 13 \overbrace{13 \quad 13}^{\mathrm{VI}}
$$

All of them are relatively short and slender, with subequal length in both rami, except only the first cirrus having the anterior ramus about $3 / 4$ as long as the posterior. Four pairs of bristles are on the front of each segment.

Caudal appendage minute, one-jointed, conical, with only 2 terminal bristles as long as the appendage itself.

Mouth-parts are ordinary as figured in Fig. 2.

The animal as here described is a female with no trace of a penis.

Complemental male. In a specimen (Cat. No. 138) only one lodged in a pouch situated on the inner side of the scutum near the occludent margin. The form resembles closely that of Scalpellum velutinum Hoek and S. formosum Hoek (cf. Hiro, 1933a, p. 30, fig. 9) in the transverse arrangement of minute hairs and the presence of two hairy patches near the pole. No trace of valves and no antennae. Musclefibres of the sac very distinct, but opening of the sac hardly visible.

Remarks. By the shape of the plates in the capitulum and their remarkable riblets radiating from the umbo, the present specimens may be referable to Scalpellum vitreum Hoek which was collected by the "Challenger" from the south of Bôsô Peninsula at the depth of 1875 fathoms. Originally this species was represented by a single specimen, lacking a male. 


\section{Family Oxynaspididae}

\section{Oxynaspis celata DARWIN}

Oxynaspis celata DARWIN, 1851, p. 134, pl. 3, fig. 1 (type locality: Madeira, eastern Atlantic); Weltner, 1897, p. 242; Nilsson-CANTEll, 1921, p. 226, fig. 37; BRoch, 1922, p. 275, figs. $32-33$ (as forma japonica).

Material. Crust. No. 146. 9 specimens attached to Antipathes sp. Maruyama-dasi, Amadaiba, 50 fathoms. 3-VIII-1934。

Among them the largest one is measured $12 \mathrm{~mm}$ in total length. All the plates are closely fitting and covered with spiny bark; the scutum has an evenly rounded baso-lateral angle, instead of right-angled as in $O$. pacifica Hrro which is more common in Japanese waters.

Range. Widespread in tropical and warm temperate seas, on antipatharians. Earlier recorded from Japanese waters by the authors listed above.

\section{Family Lepadidae}

\section{Lepas anatifera LinNAEUS}

Material. Crust. No. 140. A large specimen on a floating bamboo. Akitani, Hayama. 15-I-1929.

Crust. No. 253. Juveniles on a floating timber. Issiki, Hayama. 24-II-1929.

Crust. No. 524. Juveniles on a floating timber. Off Samezima, Hayama. 15-VII1949.

Crust. No. 1138. 2 specimens attached to a buoy. Off Issiki, Hayama. 14-VII1956.

Range. Cosmopolitan, pelagic in all seas.

\section{Lepas anserifera LINNAEUS}

Material. Crust. No. 145. 23 specimens on a floating bamboo and 3 on a pumice stone. Akitani, Hayama. 15-I-1929.

Range. Cosmopolitan, pelagic in all seas.

\section{Lepas hilli (LEACH)}

Material. Not contained in the collection of the Biological Laboratory of the Imperial Household.

Only once I collected this species on the beach of Zyôgasima, south of Misaki, in July, 1931. This species is very alike L. anatifera, so that it may be sometimes confused with the latter. The material I have collected is now deposited in the collection of the Seto Marine Biological Laboratory.

Range. Cosmopolitan, pelagic in all seas. 


\section{Lepas fascicularis ELLIS et SOLANDER}

Material. Not contained in the collection of the Biological Laboratory of the Imperial Household.

But I collected ten specimens attached to a floating kelp at Misaki, in July, 1931, which are also in the collection of the Seto Marine Biological Laboratory. They measured 9 to $47 \mathrm{~mm}$ in length and encrusted wholly with Obelia-like hydroid colonies.

Range. Cosmopolitan, pelagic in all seas.

\section{Alepas pacifica PILSBRY}

Alepas pacifica Pilsbry, 1907a, p. 105, fig. 36 (type locality: north of San Francisco, California); NilsSON-CANTELl, 1921, p. 243, fig. 42; Hiro, 1937b, p. 404, fig. 7 (synonymy).

Material. Not contained in the collection of the Biological Laboratory of the Imperial Household.

In the collection of the Seto Marine Biological Laboratory, there is a specimen attached to the oral arm of a medusa Pelagia panopyra which I obtained at Misaki. The scuta were not found in this specimen (about $20 \mathrm{~mm}$ long).

Range. Widespread in tropical and temperate seas, as attached to pelagic medusae.

\section{Family Heteralepadidae}

\section{Heteralepas (Heteralepas) japonica (AURIVILLUS)}

Alepas japonica Aurivillius, 1894, p. 28, pl. 2, figs. 14-15; pl. 8, figs. 3 \& 7; pl. 9, fig. 3 (type locality: Hirado Strait, $80 \mathrm{~m}$ ).

Heteralepas (Heteralepas) japonica HiRo, 1933a, p. 48, figs. 13-14 (synonymy).

Material. Crust. No. 137. 7 specimens attached to a Cirrhipathes-stem. West of Kamegisyô, 45 fathoms. 5-IX-1935.

Crust. No. 203. Numerous specimens crowded on a Cirrhipathes-stem. West of Kamegisyô, 40 fathoms. 14-VIII-1936.

Crust. No. 1127. 2 specimens attached to an Antipathes-stem, together with Balanus poecilotheca KRÜGER, all covered by an orange-colored colony of Clavularia mikado Utinom. Between Maruyama-dasi and Kannonzuka-dasi, 60-80 m. 13-VII1956.

Range. Japan and Indo-Malayan seas.

\section{Heteralepas (Paralepas) globosa Hiro}

Heteralepas (Paralepas) globosa Hiro, 1936, p. 221, fig. 1 (type locality: Tosa Bay, Kôti Pref., 30-100 fathoms); Hiro, 1937a, p. 74, fig. 62.

Material. Crust. No. 136. 2 specimens attached to a dead shell. 4 miles south of Zyôgasima, 400-500 m. 4-IX-1935. 
Description. Two specimens contained in this collection agree fairly with the figure and descriptions of Heteralepas (Paralepas) globosa earlier described from Tosa Bay. The specimens are larger than those given earlier by me, as shown in the following measurements.

$\begin{array}{lcc}\text { Length of capitulum } & 21.5 \mathrm{~mm} & 16.0 \mathrm{~mm} \\ \text { Breadth of capitulum } & 17.0 & 14.0 \\ \text { Thickness of capitulum } & 14.0 & 11.0 \\ \text { Length of peduncle } & 11.2 & 11.0 \\ \text { Diameter of peduncle } & 8-9 & 7.5 \\ \text { Length of orifice } & 4.5 & 3.2\end{array}$

Capitulum oval in lateral view, about $3 / 4$ as wide as long, not much compressed laterally and broadly rounded dorsally without carinal crest. Integument very thick and hard, with smooth surface. Orifice relatively small, not protuberant, with puckered lips, its length about $1 / 5$ of the length of capitulum itself. A triangular patch indicating the position of the scutum is found on each side below the orifice.

Peduncle markedly differentiated from capitulum by constrictions; shorter and narrower than capitulum.

The color is, according to a label appended, "Bittersweet pink in life, but in alcohol maple color."

The internal parts agree with those earlier described. The numbers of segments in the cirri and the caudal appendage are:

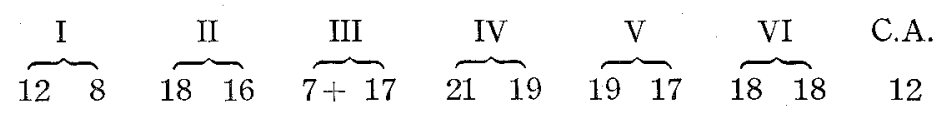

Range. Tosa Bay, 30-100 fathoms (on the gastropod shell Guildfordia triumphans); Kumanonada, 200 fathoms (on the gastropod shell Buccinum suruganum).

\section{Heteralepas (Paralepas) xenophorae (ANNANDALE)}

(Fig. 3)

Alepas xenophorae ANNANDALE, 1906, p. 399 (type locality: off S. W. coast of India, in 185 fathoms, on shell of living Xenophora).

Heteralepas (Paralepas) typica Nirsson-Cantell, 1921, p. 250, fig. 45 ; pl. 3, fig. 3 (type locality: Okinose Bank, Sagami Bay).

? Heteralepas (Paralepas) scutiger) Broch, 1922, p. 284, fig. 36 (type locality: Sagami Bay, in 400 fathoms); Brocrr, 1931, p. 41.

Heteralepas (Paralepas) xenophorae Hiro, 1937a, p. 73, fig. 61 (synonymy).

Material. Not represented in the collection of the Biological Laboratory of the Imperial Household.

1) In a foot-note (p. 233) of the same paper, Broch mentioned that "Possibly identical with Heteralepas (Paralepas) typica NILSSON-CANTELL", but later (1931) he regarded as distinct. 
Three specimens apparently referable to this species, all from Sagami Bay, are examined. One of them found at Matuwa, off Misaki, 100-200 fathoms is attached to a shell (the name of which is not recorded). The other two were collected at "Misago" Station 13 (between Itô and Hatusima, east of Izu Peninsula, 120-130 m) by Dr. T. SakaI in June, 1934, and found as attached to a living shell Xenophora pallidula (REEve).

Description. The measurements of these specimens are as follows:

$\begin{array}{llll}\quad \text { Specimen from } & \text { Matuwa } & \text { Between Itô and Hatusima } \\ \text { Length of capitulum } & 5.5 \mathrm{~mm} & 6.0 \mathrm{~mm} & 5.0 \mathrm{~mm} \\ \text { Breadth of capitulum } & 4.3 & 5.3 & 3.3 \\ \text { Length of peduncle } & 3.0 & 3.3 & 4.0 \\ \text { Breadth of peduncle } & 2.0 & 1.9 & 1.9 \\ \text { Length of orifice } & 2.0 & 2.0 & 1.5\end{array}$

Capitulum almost globular, somewhat compressed laterally only in the upper part. but without any trace of carinal ridge or crest. Apex in lateral view moderately angular, not so rounded as in the preceding species. Orifice not protuberant occupying about one-third as long as capitulum, with puckered lips. Integument white, nearly translucent, with shallow, more or less reticulated stripes on the surface; this striation may be due to the contraction of musculature by the preservation in alcohol for many years. Apparently no scuta.

Peduncle shorter than capitulum, cylindrical and irregularly wrinkled.

For examination of the internal parts, a specimen from Matuwa was dissected.

Cirri are relatively short and not curled. The numbers of segments in the rami of the cirri are:

$$
\overbrace{9 \quad 9}^{\mathrm{I}} \overbrace{17 \quad 17}^{\mathrm{II}} \overbrace{18 \quad 17}^{\mathrm{III}} \overbrace{18}^{\mathrm{IV}}=\overbrace{18 \quad 18}^{\mathrm{V}} \overbrace{18 \quad 18}^{\mathrm{VI}}
$$

Each segment exhibits the armature typical of the subgenus Paralepas. At the base of cirrus I a well developed digitiform filamentary appendage is situated. Caudal appendage is a little longer than the protopodite of cirrus VI, consisting of 10 segments. Penis comparatively short, stout, tapering and annulated all over, except on the proximal and distal parts, and planted with long hairs sparsely.

Mouth-parts are also typical of the subgenus Paralepas. Labrum with a single row of small denticles along the inner edge. Palpus conical, with bristles arranged along the inner edge.

Mandible with 4 teeth, of which the fourth at the lower angle. Inferior edge of the lower three teeth is strongly pectinated, while superior edge of the second and fourth only slightly pectinated.

Maxilla I with a distinct notch below the uppermost one large and two smaller spines; below the notch the cutting edge is densely armed with spines of irregular length. 
Maxilla II with a continuous row of rather short bristles along the frontal edge and a tuft of longer bristles at the posterior upper edge, leaving a wide gap between.

Range. Known only from the localities listed above, usually on shell of living Xenophora.

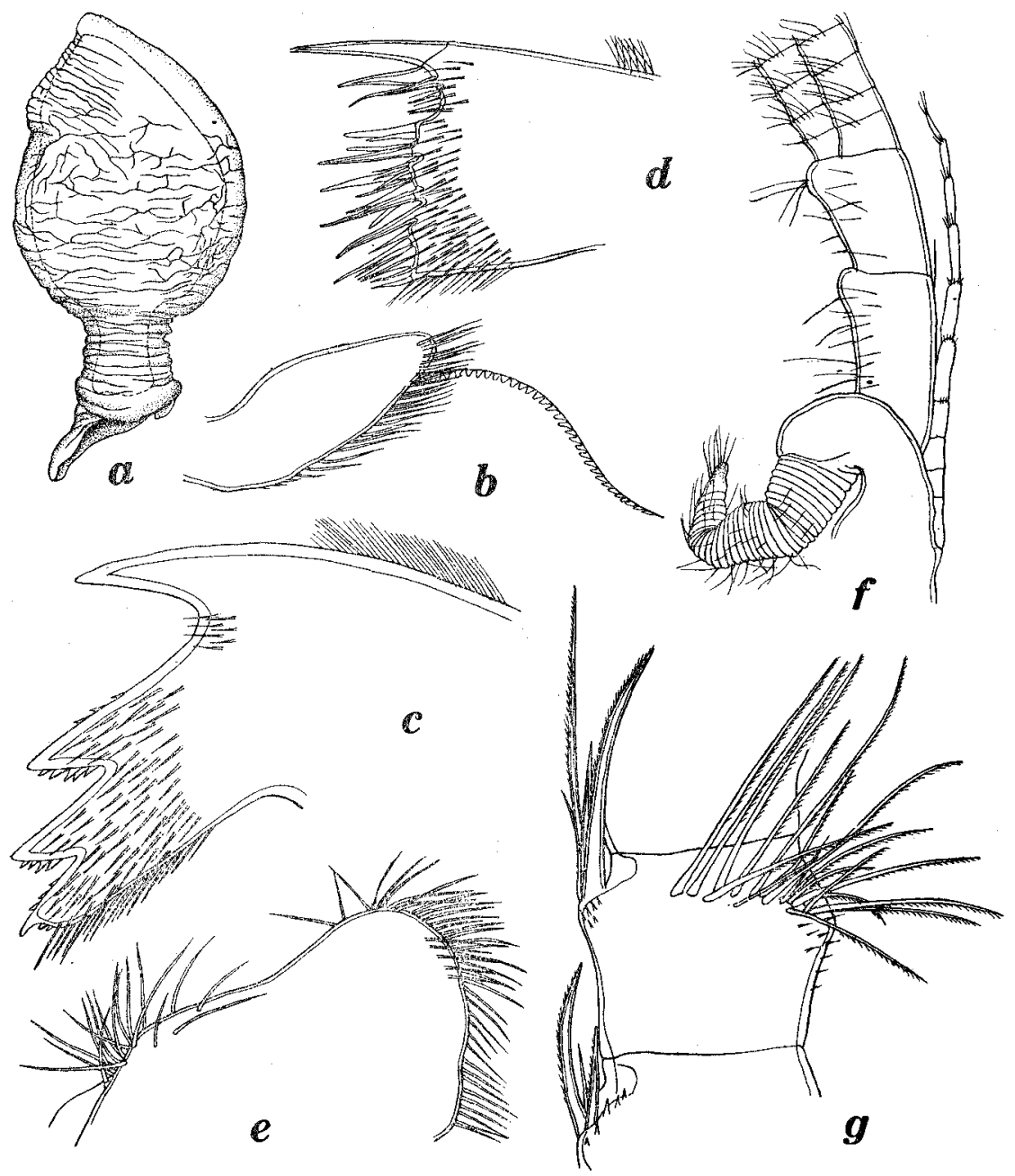

Fig. 3. Heteralepas (Paralepas) xenophorae (AnNandale).

$a$, Animal, lateral view. $b$, Labrum and palpus. $c$, Mandible. $d$, Maxilla I.

$e$, Maxilla II. $f$, Basal part of cirrus VI, with caudal appendage and penis.

$g$, Intermediate segment of cirrus VI. $(a \times 6, b-e \times 70, f \times 33, g \times 145)$

Remarks. The present specimens must in my opinion be referred to Heteralepas (Paralepas) xenophorae originally described from the southwest coast of India, both being found on the shell of living Xenophora. NILsson-Cantell (1921) described H. (P.) typica and Broch (1922) also H. (P) scutiger, both from Sagami Bay as 
separate species, although recognizing a close affinity of their species with ANNANDALE's species. The fact that NILSSON.CANTELL's specimen was also taken from a shell of Xenophora (as inferred from the photograph given by him) in Sagami Bay suggests that they are possibly identical. All the morphological characters do not differ so much that they must be kept apart.

\section{Family Poecilamatidae}

(=Fam. Trilasmatidae)

\section{Megalasma (Megalasma) striatum HoEK}

(Fig. 4)

Megalasma striatum HoEK, 1883, p. 51, pl. 2, figs. 5-9; pl. 7, figs. 8-9 (type locality: Philippine Archipelago, 210m, on Echinus); HoEK, 1907, p. 31; BROCH, 1922, p. 270, figs. 29-30; BROCH, 1931, p. 33; Hiro, 1937a, p. 99, fig. 81; Nilsson-CANTElL, 1938, p. 29.

Material. Not represented in the collection of the Biological Laboratory of the Imperial Household.

A specimen deposited in the collection of the Seto Marine Biological Laboratory registered as No. Rare 83 was taken at west of Yodomi, Okinose Bank, off Misaki, between $80-280$ fathoms.

Description. The specimen which is figured already in Hiro's book (1937a, p. 99, fig. 81) measures: Length of capitulum $10 \mathrm{~mm}$, breadth of capitulum $5 \mathrm{~mm}$, length of peduncle about $1 \mathrm{~mm}$.

This very little known species lacks almost the description of the internal parts. Although the general structure is almost alike that in other species as given by Pilsbry (1907b), Hoek (1907) and CALMAN (1919), the following supplementary account may be helpful for future comparison.

All the cirri are relatively long and slender, each segment having four pairs of large and one pair of small bristles on the frontal face. Cirrus I is widely separated from the remaining cirri and on dorsum of the prosoma near the posterior end, a single pair of rather long filamentary appendages are situated together. The caudal appendage is unique in filiform, shorter than half the length of the basal segment of the protopodite of cirrus VI. The numbers of segments in the cirri are:

$$
\overbrace{10 \quad 8}^{\text {I }} \overbrace{15 \quad 18}^{\text {II }} \overbrace{19 \quad 19}^{\text {III }} \overbrace{20 \quad 21}^{\text {IV }} \overbrace{17 \quad 18}^{\text {V }} \overbrace{20 \quad 19}^{\text {VI }}
$$

Penis is long, stout and bears long hairs.

Of the mouth-parts, labrum has distinct denticles arranged in a row along the inner edge. Palpus narrowly conical, with bristles on the inner edge, becoming longer distally.

Mandible with four teeth and a shorter lower angle. 
Maxilla I with a deep notch below the upper large spines. Below the notch the frontal edge projects and is closely spinose, as usual.

Maxilla II quadrangular in lateral view, bearing long bristles along the whole edge.

Range. Indian Ocean, Malay Archipelago, Japan. On spines of echinoids.

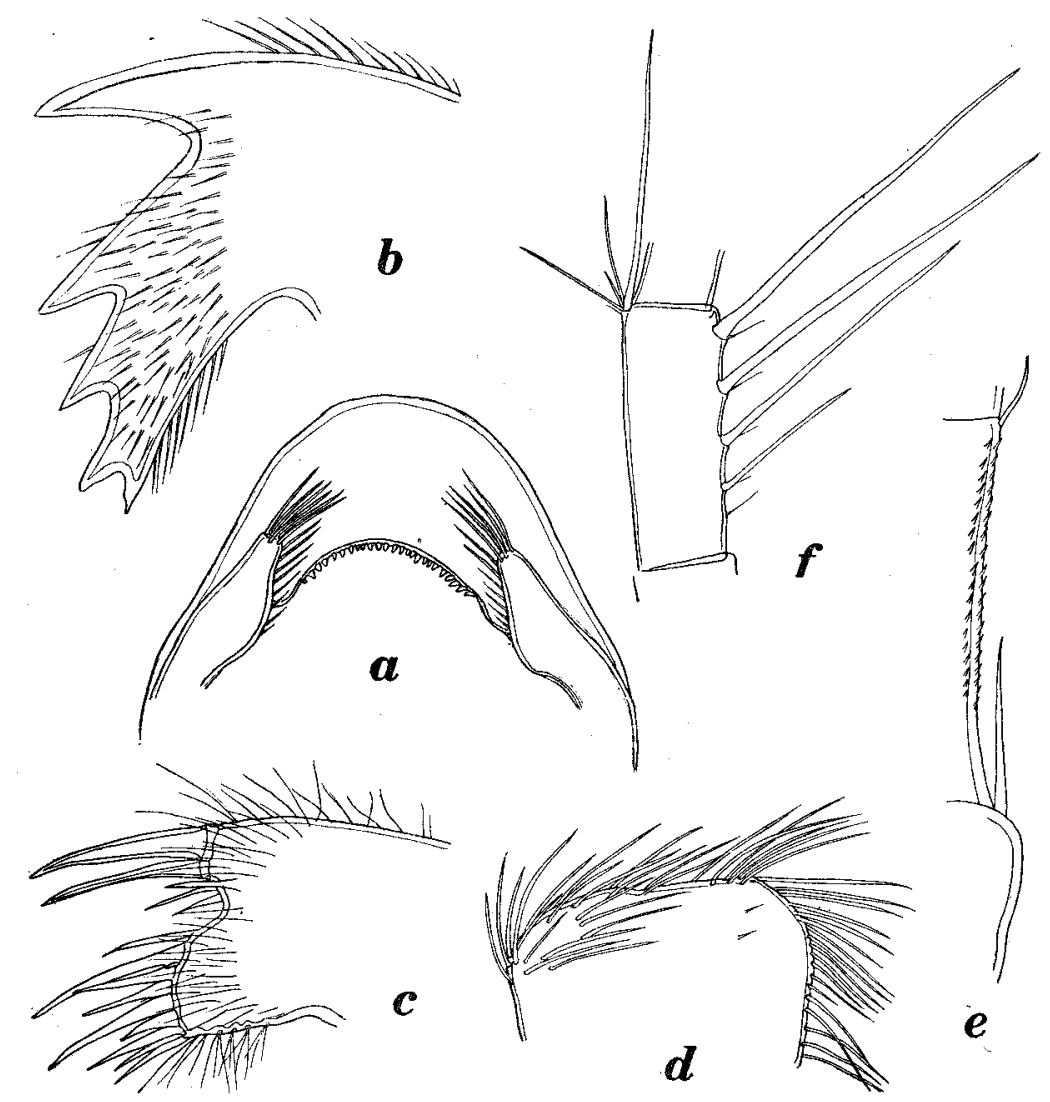

Fig. 4. Megalasma (Megalasma) striatum HoEk.

$a$, Labrum and palpi. $b$, Mandible. $c$, Maxilla I. $d$, Maxilla II. $e$, Caudal appendage. $f$, Intermediate segment of cirrus VI.

$(a-d \times 70, e \times 60, f \times 55)$

\section{BALANOMORPHA}

\section{Family Balanidae}

\section{Subfamily Balaninae}

\section{Balauus tintinnabulum volcano PILSBRY}

Material. Crust. No. 147. 17 specimens, together with Tetraclita squamosa. Teidohama, Mitune-mura, Hatizyô Island. 29-V-1929. 
Range. Southern coast of Japan, from Bôsô Peninsula to Tanegasima south of Kyusyu. Lowest of intertidal.

\section{Balanus tintinnabulum rosa PILSBRY}

Material. Crust. No. 1137. 7 specimens attached to a buoy. Off Issiki, Hayama. 14-VIII-1956.

Range. All the seas around Japan, from Mutu Bay to Formosa. Subtidal.

\section{Balanus poecilotheca KRÜGER}

Balanus poecilotheca KRÜGER, 1911, p. 48, p1. 1, figs. 2c-e; p1. 3, fig. 32 (type locality: Okinose Bank, Sagami Bay); PILSbry, 1916, p. 110; BARNARD, 1924, p. 71.

Balanus amphitrite poecilotheca HiRo, 1937b. p. 435, figs. 22-23 (synonymy).

Material. Crust. No.1127. 4 specimens attached to a dead stem of antipatharians, together with Heteralepas (Heteralepas) japonica, all covered with a stoloniferan Clavularia mikado Utrinomi. Between Maruyama-dasi and Kannonzuka-dasi, $60-80 \mathrm{~m}$. 14-VIII-1956.

Range. Japan, Malay Archipelago, South Africa, 20-290 m. Usually on dead gorgonian stems.

Remarks. Earlier I have pointed out that Balanus amphitrite poecilosculpta which was described by Broci (1931) and later by Nilsson-Cantell (1934) from South China and Malay Archipelago, seems identical with this species and regarded it as a subspecies of Balanus amphitrite. Having now studied a long series of the latter, I have reconsidered the matter and believe that KRÜGER and PILSBRY are right in separating it from various forms of $B$. amphitrite as a distinct species. The latter is mostly intertidal in habitat and rather larger in size; besides, the color markings and sculpture on the shell are quite different and rather more related to those of deep-water forms like $B$. trigonus.

\section{Balanus trigonus DARWIN}

Material. Crust. No. 1137. 9 specimens on Balanus tintinnabulum rosa. Off Issiki, Hayama. 14-VII-1956.

Range. Widespread in Pacific, Indian and Atlantic Oceans.

\section{Balanus rostratus rostratus HoEK}

Material. Crust. No. 1323. 10 specimens (mostly $20 \mathrm{~mm}$ high) attached to stones. Kannonzuka-dasi, Amadaiba, 60 m. 19-VII-1957.

Crust. No. 1338. 12 specimens ( $9-19 \mathrm{~mm}$ in diameter) clustered on a gastropod shell Bursa dunkeri KurodA. Maruyama-dasi, Amadaiba, 65 m. 23-VII-1957. 
Range. Northern Pacific, from Puget Sound to Japan through Alaska. In Japanese waters, it extends as far south as Sagami Bay, but penetrates further into Seto Inland Sea probably through the Sea of Japan, as hitherto not found in the area of Kurosio current except northwards.

\section{Balanus rostratus apertus PILSBRY}

(Fig. 5)

Balanus rostratus apertus PiLsBry, 1911, p. 74, fig. 6 ; pl. 12, figs. 4, 7; pl. 13, figs. 1, 2, 8, 9 (type locality: Bering Sea in 43 fathoms); PILsBry, 1916, p. 144, pl. 36, figs. 3-6; pl. 37 , figs. 1-1c.

Balanus rostratus var. spiniferus NiLSSON-CANTELI, 1932, p. 20, figs. 8-9; pl. 1, fig. 4 (type locality: Kobe, Japan). New combination.

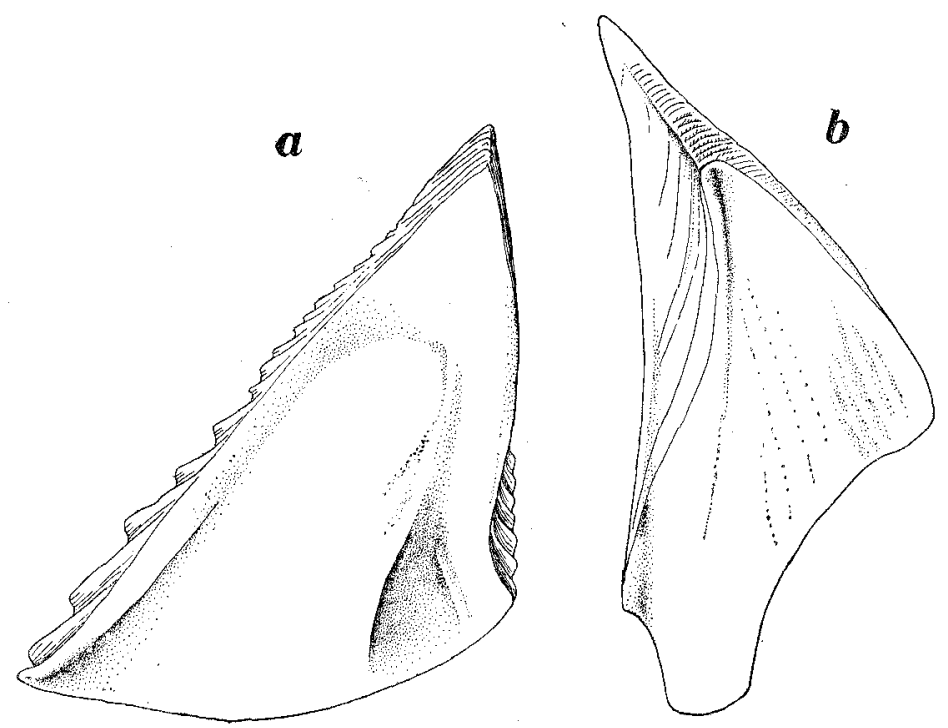

Fig. 5. Balanus rostratus apertus PILSBRY.

$a$, Scutum, inner view. $b$, Tergum, inner view. $(\times 9)$

Material. Crust. No. 1217. One specimen, probably imbedded in sponge. Kannonzuka-dasi, Amadaiba, 70-75 m. 16-I-1957.

Description and remarks. The single isolated specimen is snow white, of a conic form curved rostralward, with a relatively small orifice. All the parietes bear a number of acute spines projecting downward, each arranging longitudinally; longest spine exceeds $2 \mathrm{~mm}$ in length; growth-lines faintly defined. The radii are wide, with the upper edges almost parallel to the base. They are not so deeply sunken below the parietes as in the typical form. The basis is deeply hollowed but externally quite smooth, with no indication of calcifying together by attachment to any solid object. This suggests its being embedded in sponges.

The spines on the parietes are admirably adapted to keep the shell itself firmly 
to growing sponges but to keep the orifice freely upward so as to be not buried wholly. This reminds one of spinose species of Acasta.

As to the habitat, PILSBry (1916, p. 147) mentions that "The typical form of apertus is almost always on sponge, but sometimes on shells." Nilsson-Cantell (1932)'s var. spiniferus recorded from Kobe was also found as embedded in a sponge. In my opinion, however, the difference between apertus and spiniferus concerning the number of paired bristles on the segments of the cirri is probably due to age of individuals.

The present specimen from Sagami Bay is intermediate in size between the specimens of PILSBRy and of NiLsson-Cantell, as showing in the following measurement.

Carinorostral diameter $18 \mathrm{~mm}$, height of rostrum $10 \mathrm{~mm}$, height of carina (strongly curved) $23 \mathrm{~mm}$, diameter of orifice $7 \mathrm{~mm}$.

The opercular valves, as figured here, resemble closely those of $B$. rostratus; in particular, the tergum is not so narrow as figured for apertus as well as spiniferus.

The mouth-parts agree fairly well with the descriptions given by the two authors. The numbers of segments in the cirri are given below in comparison with those given by them.

Diam. $11.5 \mathrm{~mm}$

\begin{tabular}{|c|c|c|c|c|c|c|c|c|c|c|}
\hline \multicolumn{2}{|c|}{ I } & \multicolumn{2}{|c|}{ II } & \multicolumn{2}{|c|}{ III } & \multicolumn{2}{|c|}{ IV } & \multicolumn{2}{|l|}{ V } & VI \\
\hline 12 & 25 & 13 & 15 & 14 & 16 & 36 & 37 & 34 & 35 & $34 \quad 34$ \\
\hline 12 & 27 & 16 & 15 & 17 & 17 & 36 & 36 & - & - & -- \\
\hline 15 & 27 & 15 & 19 & 12 & 19 & 35 & 35 & 35 & 35 & $35 \quad 35$ \\
\hline
\end{tabular}

(after NILSSON-CANTELL)

(the present specimen)

Diam. $33 \mathrm{~mm}$

(after PILSBRY)

The numbers of segments in the cirri are thus not much different irrespective of the size of the shell. Each segment of the posterior longer cirri bears, according to Pilsbry, 6 or 7 pairs of bristles on the frontal side, while according to NilssonCANTELI, 4 pairs. In the present specimen, however, it bears only 3 pairs in the fourth cirri, the remaining longer ones being lost.

Henry (1940) synonymized Nilsson-Canteli's spiniferus and Pilsbry's hetero. pus with subsp. alaskensis without any discussion. But it may be improbable.

Range. Alaska and Japan (Kobe). Usually imbedded in sponges.

\section{Balanus calceolus DARWIN}

Material. Crust. No. 1337. 2 specimens on a branch of Melithaea sp. Maruyamadasi, Amadaiba, 65 m. 23-VII-1957.

The specimens in the collection of the Seto Marine Biological Laboratory, which were taken at Misaki, are found attached to the stem of Acalycigorgia irregularis KüKEnTHAL \& GoRZAwSKY.

Range. West coast of Africa, Mediterranean (?), Indian Ocean, Australia, Malay Archipelago, Japan. On gorgonian stems. 


\section{Balanus cymbiformis DARWIN}

Material. Not contained in the collection of the Biological Laboratory of the Imperial Household.

Four specimens of this species attached to the stem of Melithaea flabellifera (KüKenthal), taken at Misaki, are now in the collection of the Seto Marine Biological Laboratory.

Range. Indian Ocean, Malay Archipelago, Fiji Islands. On gorgonian stems.

\section{Acasta fenestrata DARWIN}

(Figs. 6-7)

Acasta fenestrata DARWIN, 1854, p. 316, pl.9, figs. 7a-c (type locality: Philippine Archipelago); WeltNer, 1897, p. 259; Weltner, 1922, p. 104; Nilsson-CANTEll, 1938, p. 57 ; Hiro, 1939 a, p. 243 .
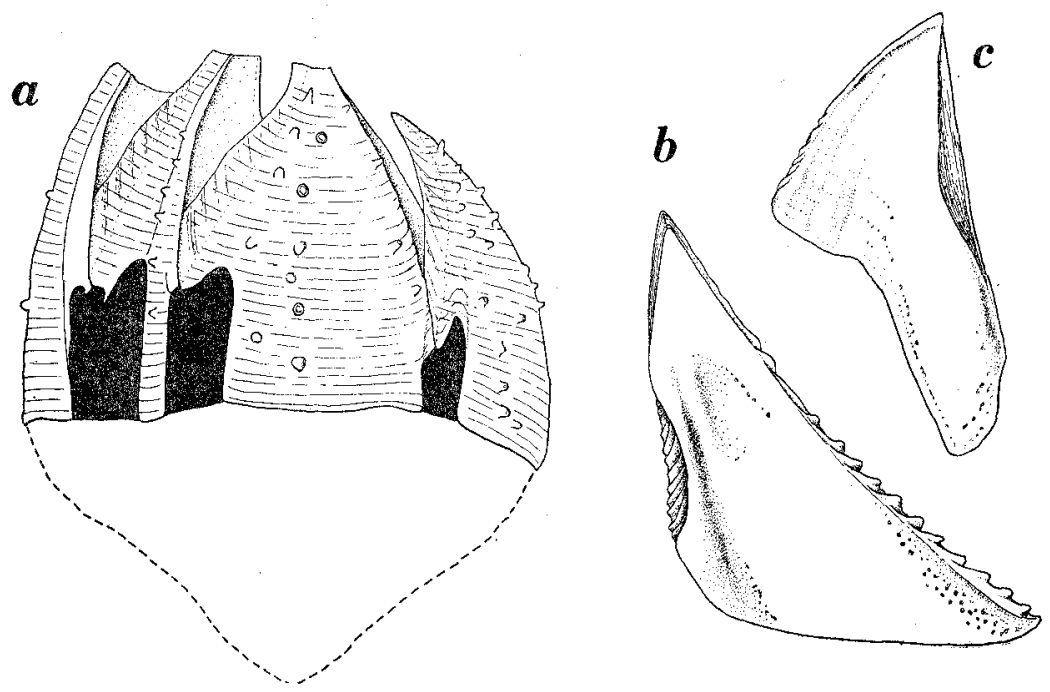

Fig. 6. Acasta fenestrata DARWIN.

$a$, Specimen (1375) in side view. b, Scutum, inner view.

$c$, Tergum, inner view.

$(\times 9)$

Material. Crust. No. 1324. 4 dead specimens wholly buried in a Geodia-like hard tetraxon sponge. Kannonzuka-dasi, Amadaiba, $60 \mathrm{~m}$. 19-VII-1957.

Crust. No. 1375, 2 specimens in soft silicious sponge. Kamnonzuka-dasi, Amadaiba, 60-65 m. 29-VII-1957.

Description. This species was first recorded by WeLtNer from off Enosima, Sagami Bay and later by the author from the vicinity of Seto, Kii Peninsula.

The general structure of the shell has been fully described by DARwin, but the 
internal structure is quite unknown, so that the following detailed ciescription based on this new material may be useful as a supplement.

The shell is firmly connected with the hard sponge tissue by calcareous points studded on the surface and all the compartments are not so tightly articulated together, having a large 'window' inserted between the base of them. So it is very difficult to dissect out intact specimens from the sponge.

The points on the parietes are rather sparsely arranged in longitudinal rows. They are generally small, roundly ended and empty, sometimes with hollowed tip; but as far as it could be observed, this 'hollow' does not penetrate the compartment itself.

The compartments are externally striped transversely parallel to the basal margin, but not on the alae. The radii are well developed with delicate striations running on the cross; below the radii, the edges of the compartments themselves are deeply hollowed out, indicating a wide gap (or window) between the opposed edges of the walls. The size of these windows may be variable in different specimens, but that between the carina and carinal latus seems to be largest. Thus the paries of the carinal latus extended down to the basis is narrowest among all compartments, only about $1 / 8$ as wide as the lateral compartment at base.

All the parietes are internally quite smooth down to the basis, and not canaliculated. Also the base is not canaliculated, usually cup-shaped and brittle.

Measurements of four specimens are:

$\begin{array}{lllll}\text { Carinorostral diameter } & 8.5 \mathrm{~mm} & 7.0 \mathrm{~mm} & 5.5 \mathrm{~mm} & 4.5 \mathrm{~mm} \\ \text { Height of compartment } & 5.5 & 5.5 & 3.4 & 6.0 \\ \text { Depth of basal cup } & 3.5 & 6.0 & 1.0 & ?\end{array}$

Scutum is rather thick, triangular and a little higher than broad. The external surface is slightly concave, marked with strong growth-lines, crossed by faint radiating stripes. Internally there is a deep but narrow longitudinal furrow between the articular and adductor ridges both of which are low. The pit for the adductor muscle is only faintly indicated.

Tergum is slightly furrowed along the line of spur. The scutal margin is straight, with a low articular ridge. The spur is rather long, about half as wide as the valve and roundly ended; its carinal margin is straight and parallel to the scutal margin of the valve itself. Crests for the depressor muscles are only slightly indicated.

Numbers of segments of the cirri in a smallest but perfect specimen dissected are as follows:

$$
\overbrace{24 \quad 8}^{\text {I }} \overbrace{13 \quad 12}^{\text {II }} \overbrace{15 \quad 13}^{\text {III }} \overbrace{18 \quad 22}^{\text {IV }} \overbrace{28 \quad 27}^{\text {V }} \overbrace{32 \quad 30}^{\text {VI }}
$$

In cirrus $\mathrm{I}$, the anterior ramus is three times as long as the posterior. In cirrus II and III, the anterior ramus is a little longer than the posterior. Whereas the other posterior cirri have each the rami of subequal length. 
The armature of the cirri is peculiar. Cirrus IV bears 1-3 large hooks on each segment of the anterior ramus, except on the proximal and distal parts, but none on the protopodite. In all cirri, the protopodite is considerably long; in cirrus I-III, its basal segment bears long feathered bristles, while in cirrus IV-VI the dorsal margin of both the segments is fringed with fine hairs all throughout.

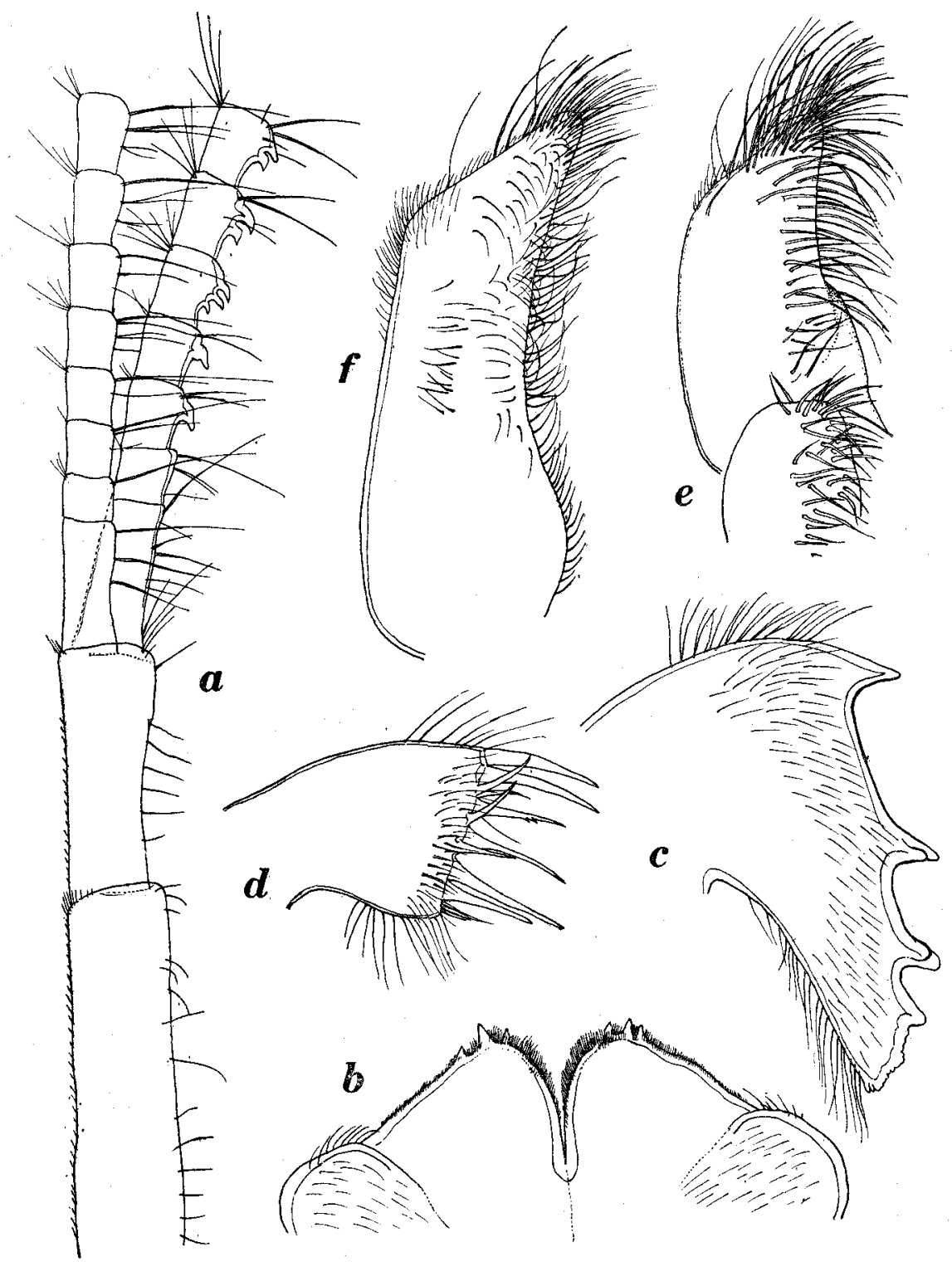

Fig. 7. Acasta fenestrata DARWIN.

$a$, Basal part of cirrus IV. $b$, Labrum. $c$, Mandible. $d$, Maxilla I. e, Maxilla II. $f$, Palpus.

$(a \times 55, b-f \times 80)$ 
The penis is very long and annulated all over.

Of the mouth-parts the labrum is the most peculiar; its cutting edge is unusually very villose and provided with 3 large denticles on each side of the wide median notch. Palpus is rhomboidal, with the straight distal margin narrowest and long bristles all around the inner margin.

Mandible has four distinct teeth of which the second and third are bifid. Below the fourth tooth the edge is finely serrated, with an indication of a diminutive denticle.

Maxilla I has a straight cutting edge without any notch. There are two large upper spines followed by a row of some six smaller spines, and on the lower part again two large spines and two tiny ones.

Maxilla II consists of two lobes, the upper elongate and the lower short oval; both are clothed with numerous bristles on the inner surface.

Range. Japan, Philippines, Indian Ocean.

\section{Acasta spongites (POLI)}

(Figs. 8-10)

Acasta spongites Darwin, 1854, p. 308, pl. 9, figs. 1a-d ; Weltner, 1897, p. 259 ; PIlsbry, 1916, p. 242, fig. 77: BARNARD, 1924, p. 80 ; KolOSVÁRY, 1947, p. 22.

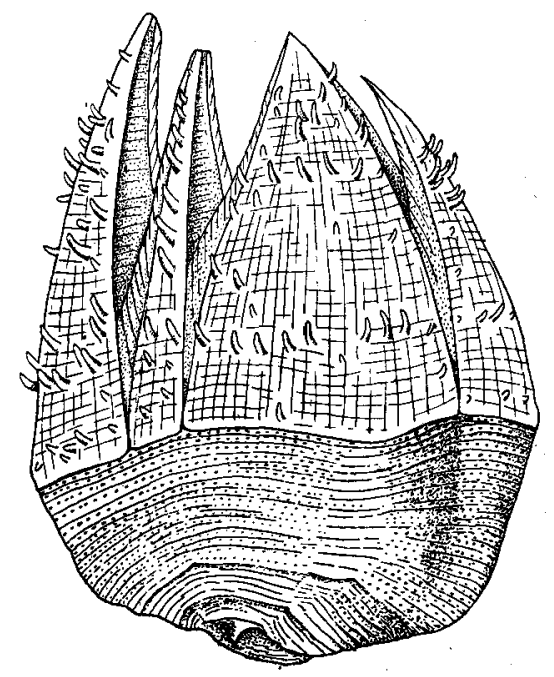

Fig. 8. Acasta spongites (POLI). ( $\times 7)$

Material. Crust. No. 1432. 14 specimens imbedded in a Hircinia-like sponge. Between Kannonzuka-dasi and Maruyama-dasi, $60 \mathrm{~m}$. 14-II-1958.

Description. This species was first recorded by Weltner (1897) from Japan based on HILGENDORF's collection, but so far has not been recorded, so that its actual existence has not been confirmed for a long time. 


\section{With the Compliments of the}

Seto Marine Biological Laboratory

Sirahama, Wakayama-ken, Japan 
The shape is usually cup-like, but variable mainly in the depth of the basal cup, as often noticed by various authors. The colour is white, or of a pinkish hue chiefly in the lower part of the shell. The surface of the compartments is furnished with many upturned, solid spines, the arrangement of which is generally irregular. The orifice is rather large and deeply notched owing to the strong obliquity of the radii and alae. The radii are well developed, but not so wide as the alae which are more sunken than the radii.

The parietes are well developed and adjoin each other basally. Carinal latus is about $1 / 5$ to $1 / 6$ as wide as the lateral compartments. Carina is longest but a little narrower than rostrum. In all compartments the sheath is a little more than half so long as the compartment. Below the sheath, the inside of the parietes is slightly ribbed.

The basal cup is generally of a regular cup-like form, and about $2 / 3$ as deep as the shell is high; sometimes it is shallower or moderately flattened, and often distorted. It is wholly or partly penetrated by small pores arranged in one row between the transverse growth ridges parallel with the brim of the cup. All the shells and basal cup are covered by a thin cuticle.

Measurements of some specimens in millimeters:

$\begin{array}{lrrrrr}\text { Carino-rostral diameter } & 8.3 & 6.8 & 6.9 & 7.2 & 6.0 \\ \text { Total height } & 11.0 & 10.6 & 9.5 & 7.3 & 6.3\end{array}$

Scutum is moderately thick, higher than wide, and has prominent growth ridges traversed by strong radiating stripes with even fade away nearer the base; the margins of these ridges are not crenate but fringed closely with hairs. The articular ridge is prominent, and the adductor ridge is rather well defined as a short mound separating the depressions for the adductor muscle and for the lateral depressor muscle.

Tergum is narrowly triangular, with a beaked apex. The spur is separated from the basiscutal angle by a narrow interspace, somewhat narrower than $1 / 3$ the entire basal breadth of the valve, and as broad as long; a flat spur-fasciole well bounded by lines runs from the apex to the truncated end. The articular ridge is rather high, but crests for the depressor muscles are feebly developed. The growth ridges of the outer surface, except on the spur-fasciole, are fringed with hairs.

Cirri of a dissected specimen show the following numbers of segments:

$$
\overbrace{16 \quad 6}^{\text {I }} \overbrace{10 \quad 7}^{\text {II }} \overbrace{13 \quad 12}^{\text {III }} \overbrace{20 \quad 25}^{\text {IV }} \overbrace{28 \quad 30}^{\text {V }} \overbrace{32 \quad 32}^{\text {VI }}
$$

In cirrus I, the anterior ramus is nearly thrice as long as the posterior. In cirrus II, the anterior ramus is a little longer than the posterior. In cirrus III, both the rami are subequal in length. In cirrus IV, the anterior ramus is shorter and rather more slender than the posterior; the regular pairs of bristles are rather crowded together in the upper part of each segment and moreover a few erect spinules, somewhat 
arranged transversely, are planted on the ventro-distal part in both the rami. In the other cirri, both the rami are subequal and each segment bears three or four pairs of bristles on the ventral surface.

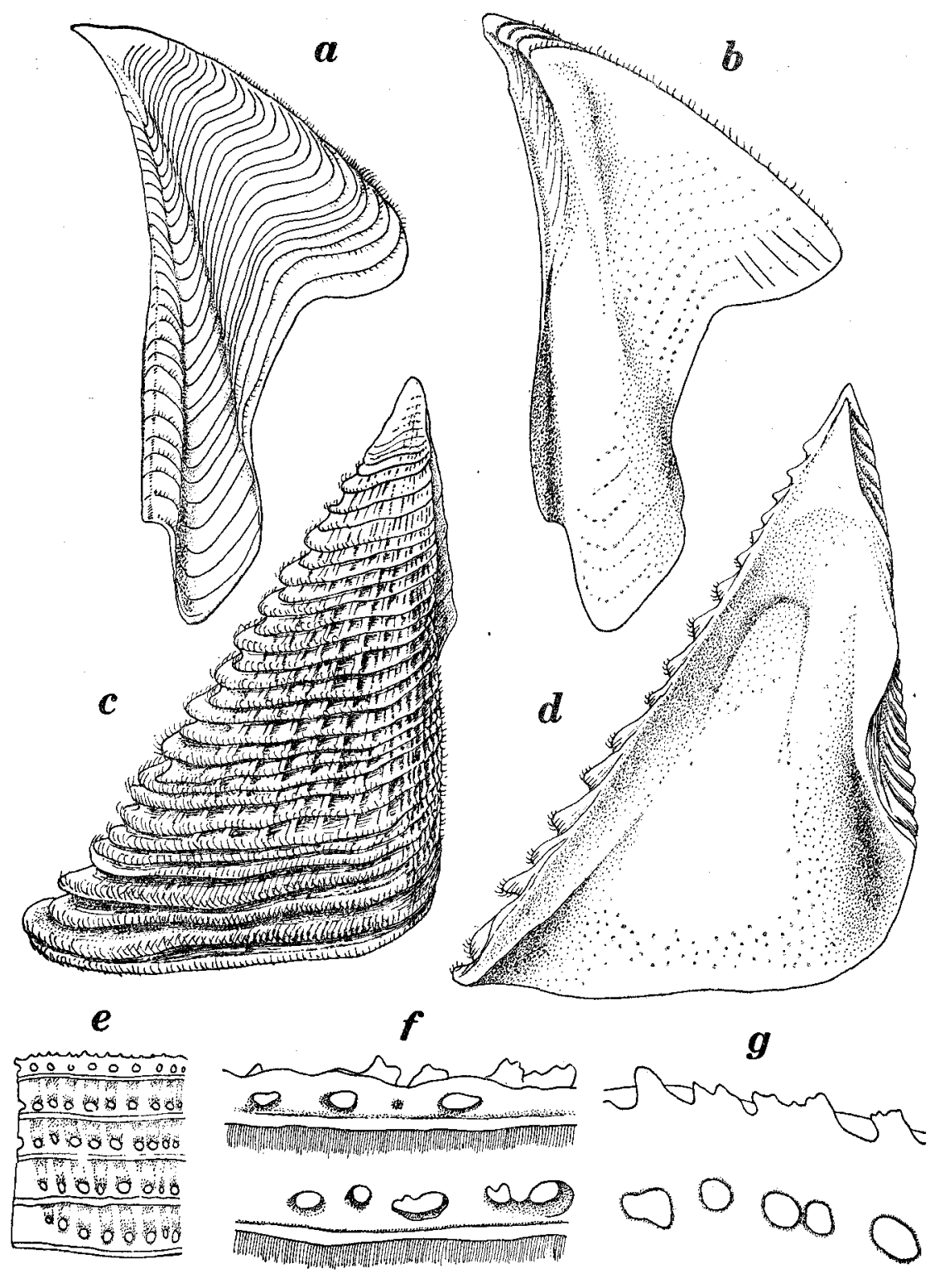

Fig. 9. Acasta spongites (POLI).

$a$, Tergum, outer view. $b$, Tergum, inner view, $c$, Scutum, outer view. $d$, Scutum, inner view. $e$, A part of basal cup, showing the cancellated structure, outer view $f$, Outer view of upper edge of basal cup, enlarged. $g$, Inner view of upper edge of basal cup, enlarged. $(a-e \times 18, f-g \times 53)$ 
The penis is long, annulated all over and hairy; no basi-dorsal point is present.

Mouth-parts: Labrum with one or two denticles on each side of the median notch.

Mandible with four large teeth and a rounded lower angle.

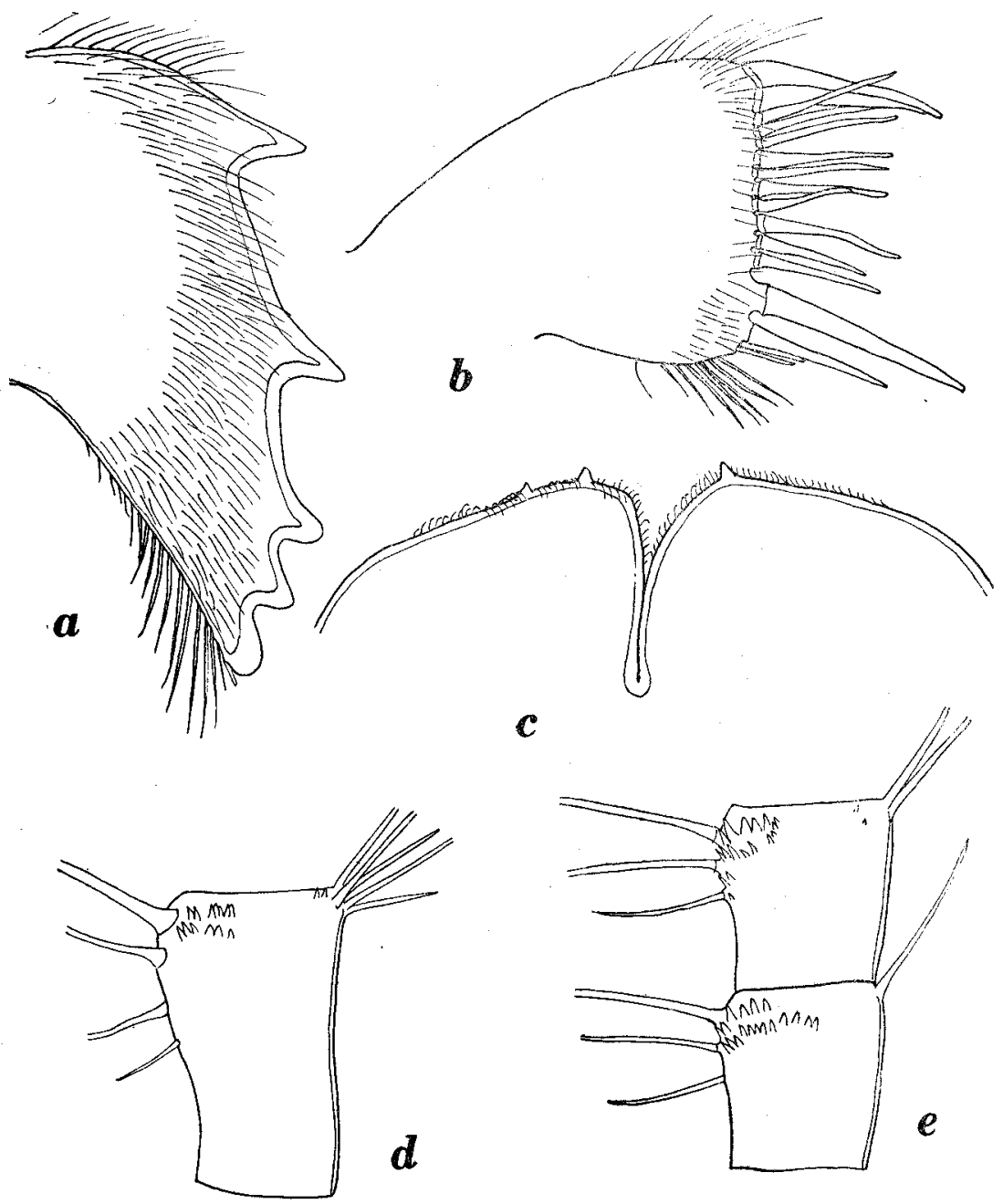

Fig. 10. Acasta spongites (PoLI).

$a$, Mandible. $b$, Maxilla I. $c$, Labrum. $d$, Median segment of posterior ramus of cirrus IV. $e$, Median segments of anterior ramus of cirrus IV.

$(a-c \times 97, d-e \times 150)$

Maxilla I has a straight cutting edge without any notch. There are two large upper spines followed by a row of ten smaller spines, and on the lower part again one large and one small spines, and terminally a few spinules.

Maxilla II is bilobed and clothed with numerous bristles on the inner surface. 
Range. North Atlantic, from British Islands to the Mediterranean; South Africa; western part of Indian Ocean; Japan (Hakodate, Sagami Bay).

Remarks. According to my former procedure (Hiro, 1937b), this species belongs to the group of 'A-type', but concerning the armature of cirrus IV it may be reckoned as one of special section of Broch's 'Eu-Acasta group', indicating a close affinity with Conopea, a subgenus of Balanus. Acasta laevigata GraY, A. semota Hiro and A. coriobasis $\mathrm{BROCH}$ have also a similar armature in the fourth cirri. Acasta japonica PILSBRY (1911), has been often treated as a subspecies or variety of Acasta spongites even now. However, it is clearly distinct as species, as pointed out already by PILSBRY (1916), the shape of the tergum being quite different and the perforation of the basal shell being not met with. Moreover, each segment of the anterior ramus in cirrus IV bears 2 or 3 large hook-like spines, in a specimen at hand dissected.

\section{Subfamily Tetraclitinae}

\section{Tetraclita squamosa viridis DARWIN}

Material. Crust. No. 147. 2 specimens. Teidohama, Mitune-mura, Hatizyô Island. 29-V-1929.

Range. Widespread in the Indo-Pacific, as far north as Sagami Bay. Also recorded from West Africa and from Panama.

\section{Tetraclita squamosa japonica PILSBRY}

Material. Crust. No. 147. 3 specimens. Teidohama, Mitune-mura, Hatizyô Island. 29-V-1929.

Range. Japan and Korea, from Tugaru Strait to Ryukyu Islands.

\section{Tetraclita (Tetraclitella) darwini PILSBRY}

Material. Not contained in the collection of the Biological Laboratory of the Imperial Household.

But this is occasionally found under stones in the intertidal zone all along the coast of Sagami Bay.

Range. Japan and Formosa.

\section{Previous Records of Cirripedia Thoracica from Sagami Bay and Its Adjacent Seas}

The littoral sessile fauna as well as the deep-sea fauna in Sagami Bay is still imperfectly known. The following list of the Cirripedia Thoracica previously recorded from Sagami Bay and its adjacent areas, including Suruga Bay, Izu Seven Islands 
and Bôsô Peninsula, is mainly derived from the works of Weltner (1897, 1922), Pilsbry (1907a, 1916), Krüger (1911, 1912), Nilsson-Cantell (1921), Broch (1922) and Hiro (1931-1938), based on the collections made by Hrlgendorf, Döderlein, loomis, Haberer, Doflein, Bock, Mortensen and by myself respectively. A comparison with the list given in my previous two papers (HIro, 1937b and 1939a) dealing with the cirripeds found in the vicinity of Seto of Kii Peninsula show that the number of species is smaller for the present, but will probably increase more by further extensive collecting. The species comprised in the collection of the Biological Laboratory of the Imperial Household, as well as those in the collection of the Seto Marine Biological Laboratory not earlier reported on from that district, are preceded in the list by an asterisk *.

\section{LEPADOMORPHA}

Scalpellidae

Mitella mitella (LINNAEUS)

Krúger 1911; Nilsson-Cantell 1921 (as Pollicipes mitella); Hiro 1932b.

* Calantica eos (PILsBry)

Prlsbry 1907a (off Osezaki, Suruga Bay, as Scalpellum (Calantica) eos) ; Hiro 1932a (as C. eos longisquama); WeItNER 1922 (? as Scalpellum (Calantica) studeri) ; Hiro 1937a.

Calantica krïgeri Hiro

KRÜGER 1911 (as C. trispinosa); WeITNER 1922 (as Scalpellum (Calantica)

trispinosum; Hiro 1932a, 1937a.

*Smilium scorpio (Aurivillius)

KRÜGER 1911 (as Scalpellum sexcornutum PILSBRY); HIRo 1932a, 1933a, 1937a

(as Calantica scorpio).

*Smilium acutum (HoEK)

Nilsson-Cantell 1921 (as Scalpellum (Smilium) acutum).

*Pisiscalpellum withersi UTINOMI

UTINOMI 1958.

Scalpellum stearnsi PILSBRY

Pilsbry 1890, 1907a, 1911 (Seno-umi, Suruga Bay); KrÜger 1911; NILsson-

Cantell 1921; Weltner 1922; Broch 1922, 1931.

Scalpellum rubrum PILSBRY

Broch 1922 ; Hiro 1937 a.

*Scalpellum vitreum HoEK

HoEk 1883 (off Bôsô Peninsula); Hiro 1937a.

* Scalpellum nipponense PILSBRY

Pilsbry 1907a; Nilsson-Cantell 1921 (as S. intermedium); Broch 1931; Hiro 1933a, 1937a. 
Scalpellum formosum HOEK

Nilsson-Cantell 1921; Weltner 1922 (as S. formosum Pilsbry), Hiro 1937a. Scalpellum condensum NiLsSON-CANTELL

Nilsson-Cantell 1921; Hiro 1937a.

Scalpellum uniarticulatum NiLSSON-CANTELL

Nilsson-Cantel 1921; Hiro 1933a, 1937a.

\section{Oxynaspididae}

Oxynaspis pacifica Hiro

Hiro 1931.

*Oxynaspis celata DARWIN

UTINOMI (this paper).

\section{Lepadidae}

*Lepas anatifera LinNAEUS

KrüGer 1911; Weltner 1922; Broch 1922.

* Lepas anserifera Linnaeus

UTINOMI (this paper).

*Lepas hilli (LEACH)

HrRo 1937b; UTINOMI (this paper).

*Lepas fascicularis ELLIS et SOLANDER

UTINOMI (this paper).

Conchoderma virgatum hunteri (OWEN)

KRÜGER 1911 (also as var. japonica), 1912.

*Alepas pacifica PILSBRy

UTINOMI (this paper).

Heteralepadidae

*Heteralepas (Heteralepas) japonica (Aurivillius)

KrüGer 1911 (also as H. (H.) indica and H. (H.) japonica var. alba); BroCH 1922.

Heteralepas (Heteralepas) quadrata (AuRIVILlius)

Krüger 1911, 1912 ; NiLsSON-CANTELl 1921 ; Hiro 1932b.

*Heteralepas (Paralepas) xenophorae (ANnANdale)

Nilsson-Canteli 1921 (as H. (P.) typica) ; Broch 1922 (? as H. (P.) scutiger); Hiko 1937a.

* Heteralepas (Paralepas) globosa Hrro

UTINOMI (this paper).

Heteralepas (Paralepas) tuberosa NILSSON-CANTELI

NiLsSON-CANTELL 1932; Hiro 1937a. 
Heteralepas (Paralepas) rosea Hiro

Krüger 1911 (as H. (P.) pedunculata); Nilsson-CANTell 1921 (as H. (P.) pedunculata ?); Hiro 1939a.

\section{Koleolepadidae}

Koleolepas avis (Hiro)

Hiro 1931 (as Heteralepas (H.) avis); HiRo 1933b, 1937a.

\section{Malacolepadidae}

Malacolepas conchicola Hiro

Hiro 1933b, 1937a.

\section{Poecilasmatidae}

Poecilasma kaempferi DARWIN

Darwin 1851; Weltner 1897, 1922; Pilsbry 1907a; Krüger 1911 (also as vai.

litum and dubium); BROCH 1922.

Temnaspis amygdalum (AURIVILLIUS)

Hrro 1937a (as Trilasmis (Temnaspis) amygdalum).

Octolasmis aymonini (LESSONA et TAPPARONE CANEFRI)

LESSONA et TAPFARONE-CANEFri 1874; WELTNER 1897 (as Dichelaspis aymonini) ;

WeltNer 1922 (as Dichelaspis trigona); KRÜGER 1911; Hiro 1937a, b.

Octolasmis orthogonia (DARWIN)

Hrro 1937a.

Octolasmis weberi pennatulae HiRo

KRÜGER 1911 (as Octolasmis weberi); HIRO 1937a, b.

*Megalasma (Megalasma) striatum HoEK

HiRo 1937a; UTINOMI (this paper).

\section{BALANOMORPHA}

\section{Chthamalidae}

Octomeris brunnea DARWIN

Hiro $1932 b$ (Miyake-zima).

Pachylasma crinoidophilum PILSBRY

NilsSOn-CANTELL 1932.

Hexelasma callistoderma (PILSBRY)

Pilsbry 1911 (Suruga Bay, as Balanus callistoderma); Krüger 1911 (as Balanus

corolliformis); PILSBRY 1916 (Suruga Bay). 
Chthamalus challengeri HOEK

Krüger 1911 (also as Ch. stellatus); Nilsson-Cantel.t 1921; Hiro 1932b

(Miyake-zima).

\section{Balanidae-Balaninae}

*Balanus tintinnabulum volcano PILSBRy

KRÜGER 1911 (as B. tintinnabulum communis); NILSSON-CANTELL 1927 (? as B. tintinnabulum peninsularis).

*Balanus tïtinnabulum rosa PILSBRY

PILsBry 1916; NilsSON-CANTELL 1932.

Balanus amphitrite communis DARWIN

WELTNER 1897 ; HIRO 1938.

Balanus amphitrite albicostatus PILSBRY

Krüger 1911 (as B. a. communis); Pilsbry 1916; Nilsson-Cantell 1921;

Hiro 1938.

Balanus amphitrite krïgeri NILSSON-CANTELL

KRÜGER 1911 (as B. a. niveus) : NilsSON-CANTEll 1932; Hiro 1938.

Balanus amphitrite hawaiiensis $\mathrm{BROCH}$

Hiro 1937b, 1938.

*Balanus poecilotheca KRÜGER

KRÜGER 1911; HIRo 1938 (as B. amphitrite poecilotheca).

*Balanus trigonus DARWIN

Weltner 1897; Krüger 1911; Pilsbry 1916; Nilsson-Cantell 1921; Broch $1922,1931$.

* Balanus rostratus rostratus HoEK

Weltner 1897 (as B. porcatus); KRÜGER 1911 (as B. crenatus); Pilsbry 1911. 1916.

* Balanus rostratus apertus PILSBRY

UTINOMI (this paper).

Balanus crenatus curviscutum PILSBRY

PILSBRY 1916.

Balanus hesperius nipponensis PILSBRY

Pilsbry 1916.

Balanus krügeri PILSBRY

Prlsbry 1916 (near Osezaki, Suruga Bay); Broch 1931.

*Balanus calceolus DARWIN

UTINOMI (this paper).

*Balanus cymbiformis DARWIN

WeLTNER 1897; UTrNOMI (this paper).

Balanus scandens PILSBRY

PILsbry 1916 (off Osezaki, Suruga Bay). 
Balanus granulatus Hiro

Hiro 1937b.

Acasta sulcata (LAMARCK)

KRÜGER 1911 ; HIRO 1937b.

Acasta dofleini KRÜGER

Krüger 1911; Nilsson-Cantell 1921; Hiro 1931 (as A. aperta), 1937 b.

Acasta denticulata Hiro

HIRo 1931.

*Acasta fenestrata DARWIN

WELTNER 1897, 1922.

*Acasta spongites (POLI)

WELTNER 1897.

Pyrgoma cancellatum LEACH

Weltner 1897 (as P. cancellatum var. japonica).

Pyrgoma aff. anglicum SowERBY

BROCH 1931.

\section{Balanidae-Tetraclitinae}

*Tetraclita squamosa japonica PILSBRY

KRÜGER 1911 (as T. porosa nigrescens); NILSSON-CANTELL 1927 (as T. porosa japonica); Hrro 1932b (Miyake-zima).

* Tetraclita squamosa viridis DARWIN

KRÜGER 1911 (as T. porosa viridis).

Tetraclita (Tetraclitella) chinensis NiLsson-CANTELL

Hiro 1931, 1932b (as T. purpurascens nipponensis).

* Tetraclita (Tetraclitella) darwini PrLSBRY

UTINOMI (this paper).

\section{Balanidae-Chelinibiinae}

Chelonibia testudinaria (LinNAEUs)

WELTNER 1897 ; KRÜGER 1911.

Chelonibia patula (RANZANI)

WELTNER 1897.

\section{LITERATURE}

ANNANDALE, N. 1906. Natural history notes from the R. I. M. S. Ship 'Investigator', Capt. T. H. Heming, R. N., commanding. Series III, No. 12. Preliminary report on the Indian stalked barnacles. Ann. Mag. Nat. Hist., Ser. 7, vol. 17, no. 100.

Auriviltms, C. W. 1894. Studien über Cirripeden. Kunglia Sv. Vetensk.-Akad. Handl., Bd. 26, no. 7 . 
BARnARD, K. H. 1924. Contributions to the Crustacean fauna of the South Africa. 7. Cirripedia. Ann. S. Afr. Mus., vol. 20.

Broch, Hj. 1924. Papers from Dr. Th. Mortensen's Pacific Expedition 1914-16. X. Studies on Pacific cirripeds. Vidensk. Medd. Dansk naturh. Foren., Bd. 73.

1931.' Papers from Dr. Th. Mortensen's Pacific Expedition 1914-16. . LVI. Indomalayan Cirripedia. Ibid., Bd. 91.

CALman, W. T. 1919. On barnacles of the genus Megalasma from deep-sea telegraph-cables. Ann. Mag. Nat. Hist., Ser. 9, vol. 4.

DARwIN, Ch. 1851. A monograph on the sub-class Cirripedia. I. The Lepadidae. Ray Society, London.

1854. A monograph on the sub-class Cirripedia. II. The Balanidae, Verrucidae, etc. Ray Society, London.

Henry, Dora P. 1940. The Cirripedia of Puget Sound with a key to the species. Univ. Wash. Publ. Oceanogr., vol. 4, no. 1.

Hrro, F. 1931. Notes on some new Cirripedia from Japan. Mem. Coll. Sci. Koyto Imp. Univ., Ser. B, vol. 7 , no. 3 .

1932a. Report on the Japanese species of the genus Calantica (Cirripedia). Annot. Zool. Japen., vol. 13 , no. 5 .

1932b. On the Cirripedia collected in Sado, Miyake Itrup Islands and Hokkaido. Zool. Mag. (Japan), vol. 44, no. 530. (Japanese.)

1933a. Report on the Cirripedia collected by the surveying ships of the Imperial

Fisheries Experimental Station on the continental shelf bordering Japan. Rec. Oceangr. Wks. Jap., vol. 5, no. 1 .

1933b. Notes on two interesting pedunculate Cirripeds, Malacolepas conchicola $\mathrm{n}$. gen. et sp. and Koleolepas avis (Hiro), with remarks on their systematic positions. Mem. Coll. Sci. Kyoto Imp. Univ., Ser. B, vol. 8, no. 3.

1936. Descriptions of three new species of Cirripedia from Japan. Bull. Biogeogr.

Soc. Japan, vol. 6, no. 23.

1937a. Order Thoracica I (Cirripedia Pedunculata). Fauna Nipponica, vol. 9, fas. 1, no. 5. Sanseidô, Tokyo. (Japanese.)

1937b. Studies on Cirripedian fauna of Japan. II. Cirripeds found in the vicinity of the Seto Marine Biological Laboratory. Mem. Coll. Sci. Kyoto Imp. Univ., Ser. B, vol. 12, no. 3. 1938. On the Japanese forms of Balanus amphitrite Darwin. Zool. Mag. (Japan), vol.

50, no. 6 (Japanese, with English rés.).

1939a. Studies on the Cirripedian fauna of Japan. III. Supplementary notes on the cirripeds found in the vicinity of Seto. Mem. Coll. Sci. Kyoto Imp. Univ., Ser. B, vol. 15, no. 2. 1939b. Studies on the Cirripedian fauna of Japan. IV. Cirripeds of Formosa (Taiwan), with some geographical and ecological remarks on the littoral forms. Ibid., vol. 15, no. 2.

1939c. Studies on the Cirripedian fauna of Japan. V. Cirripeds of the northern part of Honsyû. Sci. Rep. Tôhoku Imp. Univ., Fourth Ser., Biol., vol. 14, nos. 2/3.

HOER, P. P. C. 1883. Report on the Cirripedia collected by H. M. S. 'Challenger' during the years 1873-76. Rep. Sci. Res. Challenger, Zool., vol. 8. London.

1907. The Cirripedia of the Siboga-Expedition. A. Cirripedia Pedunculata. Siboga-Expeditie, mon, 31a. Leiden.

KRÜGER, P. 1911. Beiträge zur Cirripedienfauna Ostasiens. Abhandl. math phys. K1. Bayer. Akad. Wiss. II. Suppl. Bd. 6 Abh.

1912. Über ostasiatische Rhizocephalen. Anhang. Über einige interessante Vertreter der Cirripedia Thoracica. Ibid., 8 Abh.

LESSONA et TAPPARONE-CANEFr 1874. Nota sulla Macrocheira Kaempferi Sieb., e sopra una nuova specie del Genre Dichelaspis. Atti. della Reale Acad. Sci. Torino, vol. 9. 
Nilsson-Cantell, C. A. 1921. Cirripeden-Studien. Zur Kenntnis der Biologie, Anatomie und Systematik dieser Gruppe. Zool. Bidrag Uppsala, Bd. 7.

1927. Some barnacles in the British Museum (Nat. Hist.) Proc. Zool.
1932. Cirripedien aus Japan. Ark. Zool., Bd. 24A, no. 4. Raffles Mus., Singapore, no. 9.

1938. Cirripedes from the Indian Ocean in the collection of the Indian

Museum, Calcutta. Mem. Ind. Mus., vol. 13.

PILSBRy, H. A. 1890. Description of a new Japanese Scalpellum. Proc. Acad. Nat. Sci. Philad., 1890.

1907a. The barnacles (Cirripedia) contained in the collections of the U. S. National Museum. U. S. Nat. Mus., Bull. 60.

1907b. Notes on the cirripede genus Megalasma. Proc. Acad. Nat. Sci. Philad., 1907.

1908. On the classification of Scalpelliform barnacles. Ibid., 1908.

1911. Barnacles of Japan and Bering Sea. Bull. Bur. Fish., vol. 29.

1916. The sessile barnacles contained in the U. S. National Museum, including

a monograph of the American species. U. S. Nat. Mus., Bul1. 93.

Utinomi, H. (formerly HiRo, F.) 1949. Studies on the Cirripedian fauna of Japan. VI. Cirripeds from Kyusyu and Ryukyu Islands. Publ. Seto Mar. Biol. Lab., vol. 1, no. 2.

1958. A new stalked cirriped (Pisiscalpellum withersi n. gen. et

n. sp.) from Sagami Bay and a discussion on its phylogeny. Jap. Jour. Zool., vol. 12, no. 2.

WELTNER, W. 1897. Verzeichnis der bisher beschriebenen recenten Cirripedienarten. Arch. f. Naturg., Jahrg. 1897, Bd. 1.

1922. Cirripedia der deutschcs Tiefsee-Expedition. Wiss. Ergeb. der deutschen

Tiefsee-Exped., Bd. 23, Ht. 2. Jena. 